\title{
Report of the Annual Meeting
}

Rapports annuels de la Société historique du Canada

\section{Preserving Canada's Historic Past}

\section{National Parks Bureau, Lands, Parks, and Forests Branch et Department of Mines and Resources}

Volume 18, numéro 1, 1939

URI : https://id.erudit.org/iderudit/300194ar

DOI : https://doi.org/10.7202/300194ar

Aller au sommaire du numéro

Éditeur(s)

The Canadian Historical Association/La Société historique du Canada

ISSN

0317-0594 (imprimé)

1712-9095 (numérique)

Découvrir la revue

Citer ce document

National Parks Bureau, Lands, Parks, and Forests Branch \& Department of Mines and Resources (1939). Preserving Canada's Historic Past. Report of the Annual Meeting / Rapports annuels de la Société historique du Canada, 18(1), 142-145. https://doi.org/10.7202/300194ar

All rights reserved (C The Canadian Historical Association/La Société historique du Canada, 1939
Ce document est protégé par la loi sur le droit d'auteur. L'utilisation des services d'Érudit (y compris la reproduction) est assujettie à sa politique d'utilisation que vous pouvez consulter en ligne.

https://apropos.erudit.org/fr/usagers/politique-dutilisation/ 


\section{PRESERVING CANADA'S HISTORIC PAST}

\section{By the National Parks Bureau, Lands, Parks, and Forests Branch, Department of Mines and Resources}

The restoration, preservation, marking, and administration of historic sites of national importance and the commemoration of the public services of outstanding persons connected with the early history of Canada have been entrusted to the National Parks Bureau. The Bureau is advised in this work by the Historic Sites and Monuments Board of Canada, an honorary body, comprised of a number of recognized historians representing the various parts of the Dominion.

The personnel of the Board is as follows: Chairman, BrigadierGeneral E. A. Cruikshank, LL.D., F.R.S.C., F.R.Hist., Ottawa, Ontario ; His Honour, Judge F. W. Howay, LL.B., LL.D., F.R.S.C., F.R.Hist., New Westminster, B.C.; J. Clarence Webster, C.M.G., M.D., D.Sc., LL.D., F.R.S.C., Shediac, N.B.; Professor Fred Landon, M.A., F.R.S.C., London, Ontario; Professor D. C. Harvey, M.A., F.R.S.C., Halifax, N.S.; The Hon. E. Fabre-Surveyer, B.A., LL.M., B.C.L., F.R.S.C., Montreal, P.Q.; The Rev. Antoine d'Eschambault, D.S.T., D.J.C., St. Boniface, Manitoba; J. A. Gregory, M.L.A., North Battleford, Saskatchewan; F. H. H. Williamson, Controller, National Parks Bureau, Ottawa, Ontario.

The annual meeting of the Board was held in Ottawa from May 19 to 21 , when a number of new sites were reviewed and a selection made therefrom for attention at a later date. Of the total number of sites considered by the Board to date, 276 have now been suitably marked and 178 additional ones recommended for future attention.

During the year the following sites were marked:

Mohaze Indian Fort, Annapolis Royal, N.S.

A bronze plate affixed to an iron pedestal was erected on lower St. George Street to mark the site of the fort built in 1712 by Mohawk Indians under Major Livingston, employed as allies of the British to intimidate the Micmacs. The tablet was unveiled on August 29, 1938, under the auspices of the Annapolis Royal Historieal Association.

Battle of Grand Pré, Grand Pré, N.S.

A cut-stone monument with tablet was erected adjacent to the provincial highway to commemorate the engagement which took place on February 11, 1747, when New England troops under Colonel Arthur Noble were surprised and defeated by French and Indians under Coulon de Villiers, who had made a forced march from Beaubassin in a blinding snowstorm. The British commander was killed and the French leader died later of his wounds. The monument was unveiled on September 5, 1938. Halifax-Castine Expedition, Halifax, N.S.

A cut-stone monument with tablet was erected on the grounds of Dalhousie University to commemorate the British military and naval expedition from Halifax in September, 1814, under Lieutenant-General Sir John Coape Sherbrooke and Rear-Admiral Edward Griffith, which occupied the portion of Maine between the Penobscot and St. Croix Rivers. MajorGeneral Gerard Gosselin governed that district, from Castine, until April 
26, 1815. The customs duties collected during this period were utilized by Governor Dalhousie for the endowment of the Garrison Library and Dalhousie College. The monument was unveiled on August 16, 1938, under the auspices of the Dalhousie Reunion Committee.

First Pictou Academy, Pictou, N.S.

A cut-stone monument with tablet was erected adjacent to Church Street to mark the site of the first Pictou Academy which was erected in 1818 and demolished in 1932. Under the leadership and example of Dr. Thomas McCulloch, it opened the door of opportunity to a hitherto neglected element of the population of the Maritime Provinces and gave many prominent men to Nova Scotia and the Dominion of Canada in journalism, literature, science, theology, education, and government. The monument was unveiled on August 15, 1938.

Major Thomas Dixson, Fort Beauséjour National Park, near Aulac, N.B.

A tablet was affixed to the outer wall of the museum building in honour of Major Thomas Dixson, who during the siege of Fort Cumberland by rebels under Jonathan Eddy in 1776, made a perilous journey to Halifax, securing the assistance of a force which helped to rout the enemy and to save Nova Scotia for the Empire. The tablet was unveiled on July 24, 1938.

Prehistoric Indian Portage, Baie Verte, N.B.

A cut-stone monument with tablet was erected adjacent to the AulacPort Elgin highway to mark the route from the Gulf of St. Lawrence to the Bay of Fundy which was the chief means of communication between Quebec, Isle Royale, and Chignecto. The portage connected the Baie Verte and Missaguash Rivers. The monument was unveiled on September 4, 1938.

First Postal Service in Canada, Montreal, P.Q.

A tablet was affixed to the outer wall of the new Postal Terminal building, St. James Street, to commemorate the establishment of this service. From 1693, couriers, the first known of whom was Pierre DaSilva, called the Portuguese, carried the mail between Quebec and Montreal. In 1763 Benjamin Franklin, then Deputy Postmaster-General in North America, established the first organized postal service in Canada.

Struggle for Hudson Bay, Ville Marie, P.Q.

A cairn with tablet was erected on the Court House grounds to commemorate the capture, in 1686, of three Hudson's Bay Company forts on James Bay, by a French force under Chevelier de Troyes, assisted by Canadians under d'Iberville, journeying overland by way of Lake Temiscamingue. The French retained possession until the Treaty of Utrecht in 1713. The monument was unveiled on August 15, 1938.

\section{Trent Valley Canal, Bobcaygeon, Ontario}

A cut-stone monument with tablet was erected near the bridge over the canal to commemorate the construction, in 1833, of the first Bobcaygeon Lock by the Inland Water Commission, appointed by Sir John Colborne: the beginning of the improvement of the natural waterway connecting Lake Ontario with Georgian Bay. 


\section{First Cheese Factory in Canada, Ingersoll, Ontario}

A tablet was affixed to the Post Office building to mark the site of the first cheese factory in Canada, established in the County of Oxford in 1864. The widespread adoption of the co-operative factory system in this and other counties marked the beginning of the modern dairying industry in Eastern Canada. The Canadian Dairymen's Association was founded at Ingersoll in 1867.

Sir Arthur Currie, Sir George Ross, and the Hon. Edward Blake, London, Ontario

Bronze plates in memory of each of these outstanding persons were erected in the Court House. The unveiling ceremonies were held on November 21, 1938, under the auspices of the London and Middlesex Historical Society.

\section{Battle of Lundy's Lane, Niagara Falls, Ontario}

Three tablets bearing the names of the officers and men who were killed in this battle, which took place on July 25,1814 , were attached to the large monument erected some years ago by the Dominion Government.

\section{First Oil Wells in Canada, Oil Springs, Ontario}

A tablet was affixed to the outer wall of the Community Hall to commemorate the discovery of oil in this locality. It was observed by early travellers and by the pioneer farmers who used it for medicinal purposes. In 1858, near Oil Springs, James M. Williams dug the first oil well in Canada and later established a refinery at Hamilton. In 1861, John Shaw, by drilling into the rock, opened the first flowing well, its situation being lot 18, concession 2, Enniskillen Township. From these beginnings developed one of Canada's most important industries. The tablet was unveiled on July 1, 1938.

\section{Samuel Hearne, Churchill, Manitoba}

A tablet was affixed to the outer wall of Fort Prince of Wales to commemorate the public services of Samuel Hearne, 1745-92. Travelling overland from Port Churchill in 1771 he succeeded, after two attempts, in discovering the Coppermine River. This demonstrated that a waterway did not exist between the Pacific Ocean and Hudson Bay. In 1774 he established Cumberiand House, the first inland post of the Hudson's Bay Company. He became Governor of Fort Prince of Wales in 1775 and was in charge in 1782 when it was captured by La Pérouse.

\section{Cumberland House, Cumberland Lake, Saskatchewan}

A cairn with tablet was erected near the Hudson's Bay Company post to mark the site of this important trading house. From 1670 to 1774 all the posts of the Hudson's Bay Company were on the shore of Hudson Bay; but in 1774 , as a result of the advent of the Montreal traders, the Company built Cumberland House. Its erection marked a new era in the fur trade and the commencement of the rivalry which continued until 1821.

\section{Fort Assiniboine, near Barrhead, Alberta}

A cairn with tablet was erected in the south-west quarter of section 1 , township 62 , range 6 , west of the 5 th meridian, to commemorate the 
improvement in the early transportation system of Western Canada. In 1825 the old route across the continent by way of Churchill, Beaver, and Athabaska Rivers was changed to one by way of the North Saskatchewan as far as Edmonton, and thence by pack train to the Athabaska at Fort Assiniboine. This change resulted in greater speed, decreased cost, and increased safety.

Kootenae House, near Invermere, B.C.

A cut-stone monument with tablet was erected on lot 375 , Kootenay District, to mark the place where in August, 1807, David Thompson of the North West Company built Kootenae House, the first trading post of the white man on the Columbia River or its tributaries. During the next four years he explored the Columbia River from source to mouth, and established trade with the Indians in southern British Columbia and in much of the country now known as the States of Montana, Idaho, and Washington.

The Canadian Pacific Railway, Port Moody, B.C.

A cairn with tablet was erected on the City Hall grounds to commemorate the completion of the Canadian Pacific Railway. The "Last Spike" of this railway was driven November 7, 1885, and on the following day the first transcontinental train reached the terminus at Port Moody. On July 4, 1886, the first regular passenger train arrived at Port Moody from Montreal, thus completing the bond of union and making Canada independent in the matter of railway transportation. The monument was unveiled on October 1, 1938. 